IZA DP No. 6872

\title{
Rural Households in a Changing Climate
}

Javier E. Baez

Dorothy Kronick

Andrew D. Mason

September 2012 


\title{
Rural Households in a Changing Climate
}

\author{
Javier E. Baez \\ World Bank \\ and IZA
}

\author{
Dorothy Kronick \\ World Bank \\ and Stanford University
}

\author{
Andrew D. Mason \\ World Bank
}

\section{Discussion Paper No. 6872 \\ September 2012}

\author{
IZA \\ P.O. Box 7240 \\ 53072 Bonn \\ Germany \\ Phone: +49-228-3894-0 \\ Fax: +49-228-3894-180 \\ E-mail: iza@iza.org
}

\begin{abstract}
Any opinions expressed here are those of the author(s) and not those of IZA. Research published in this series may include views on policy, but the institute itself takes no institutional policy positions. The IZA research network is committed to the IZA Guiding Principles of Research Integrity.

The Institute for the Study of Labor (IZA) in Bonn is a local and virtual international research center and a place of communication between science, politics and business. IZA is an independent nonprofit organization supported by Deutsche Post Foundation. The center is associated with the University of Bonn and offers a stimulating research environment through its international network, workshops and conferences, data service, project support, research visits and doctoral program. IZA engages in (i) original and internationally competitive research in all fields of labor economics, (ii) development of policy concepts, and (iii) dissemination of research results and concepts to the interested public.
\end{abstract}

IZA Discussion Papers often represent preliminary work and are circulated to encourage discussion. Citation of such a paper should account for its provisional character. A revised version may be available directly from the author. 


\section{ABSTRACT}

\section{Rural Households in a Changing Climate ${ }^{1}$}

This paper argues that climate change poses two distinct, if related, sets of challenges for poor rural households: challenges related to the increasing frequency and severity of weather shocks and challenges related to long-term shifts in temperature, rainfall patterns, water availability, and other environmental factors. Within this framework, we examine evidence from existing empirical literature to compose an initial picture of household-level strategies for adapting to climate change in rural settings. We find that although households possess numerous strategies for managing climate shocks and shifts, their adaptive capacity is insufficient for the task of maintaining - let alone improving - household welfare. We describe the role of public policy in fortifying the ability of rural households to adapt to a changing climate.

JEL Classification: Q12, Q54, O13

Keywords: climate change, rural households, adaptation, risk-coping mechanisms, long-term effects

Corresponding author:

Andrew D. Mason

The World Bank

Washington, DC 20433

USA

E-mail: amason@worldbank.org 


\section{Introduction}

How will rural households in developing countries adapt to climate change? Rooted as it is in the hard sciences and in high-income communities, the public dialogue on global environmental change has only recently begun to consider the adaptive capacity of poor rural households. This inattention is not for lack of importance; the welfare of these households concerns millions. Rather, it may be for lack of definition: the issue is so broad and so complex that it seems to defy focused consideration.

One way to conceptualize adaptation in rural communities is to recognize two effectively distinct phenomena associated with climate change: first, increased weather variability and increased frequency and severity of extreme weather events (broadly, "shocks") and, second, gradual changes in temperature and rainfall patterns (broadly, "shifts"). From a climate perspective, these phenomena are not actually distinct; from the perspective of adaptation among agricultural households, however, dividing the issue into shocks and shifts provides a useful framework. Events that temporarily disrupt a household's modal environmental conditions can be considered shocks, and those that permanently change the modal conditions can be considered shifts.

Of course, the increasing frequency and severity of extreme weather events is itself a shift because it permanently changes modal environmental conditions. Likewise, gradual changes in temperature and rainfall patterns may manifest as shocks (in the form of droughts and floods, for example). By categorizing the ways in which rural households experience climate change, we clarify the relevance of several established bodies of literature. This literature includes work on ambiguity risk, agricultural technology adoption, reaction to weather-related information, determinants of migration, income diversification, health, and past experiences with permanent environmental changes. This paper synthesizes evidence from this literature to develop a more inclusive and composite picture of household-level strategies for adapting to climate change in rural settings. ${ }^{2}$ We also briefly discuss the role of public policy in fortifying households' capacity to adapt.

We describe rural households' numerous strategies for dealing with climate change, and we outline the ways in which these strategies are insufficient for the task of maintaining (let alone improving) household welfare. The threat to welfare derives not only from the direct losses associated with climate shocks and shifts but also from increased uncertainty, which complicates households' attempts to smooth consumption (with credit or insurance, for example), to smooth income (by adjusting agricultural portfolios), and to evaluate options such as migration.

The notion that some households may lack sufficient adaptive capacity or may respond in ways that have adverse long-term consequences suggests a possible role for public policy. To date, the dominant policy framework, to the extent that one exists, has focused on what has been called a no-regrets approach to climate-related adaptation policy (see Heltberg, Siegel, and Jorgensen 2009; de la Torre, Fajnzylber, and Nash 2009; and World Bank 2010). In the face of the many uncertainties associated with the future effects of climate change, the no-regrets approach emphasizes policies and investments today that can generate positive net benefits "under all future scenarios of climate change and impacts" (Heltberg, Siegel, and Jorgensen 2009). This approach has many merits, though there may also be room for more specific action. Here, we 
draw attention to country experiences with (i) better systems of information for adaptation and (ii) climate-adapted risk management instruments (such as indexed production insurance), and

(iii) social safety nets that are targetable and scalable on the basis of weather events.

The remainder of this paper is organized as follows. Section II defines key concepts related to rural households' exposure, sensitivity, and capacity to adapt to climate change. Drawing on extensive empirical literature on household responses to weather shocks, section III analyzes how - and how well-households may be expected to cope with the increased frequency and severity of weather shocks associated with climate change. Drawing on several strands of empirical literature on the determinants of household economic mobility, section IV explores how households are likely to adapt to longer-term climatic shifts. Section V discusses directions for public policy, and section VI concludes.

\section{Exposure, Sensitivity, and Household Capacity to Adapt to Climate Change}

In the literature on climate change, the concept of vulnerability comprises three elements: exposure (experience of climate conditions), sensitivity (response of the physical environment to exposure, such as the response of crop yield to temperature and precipitation), and adaptive capacity (discussed below) (IPCC 2007 and many others, notably Turner 2003 and Schröter, Polsky, and Patt 2005). This section briefly describes rural households' exposure and sensitivity to climate change and then defines adaptive capacity, which is the subject of the remainder of the paper.

Substantial effort has been devoted to generating increasingly precise projections of climate trends and the exposure of rural households to these trends. Summarizing this work is beyond the scope of this paper; below, we outline a few points that are useful for our discussion of adaptive capacity. As noted above, we organize our discussion according to two broad categories of climate changes: shocks, the increase in weather variability and the frequency of extreme weather events, and shifts, the long-term rise in global surface temperatures and related gradual changes in sea level and rainfall patterns.

Over the past century, global mean surface temperatures rose by $0.74^{\circ} \mathrm{C}$, on average (the absolute global mean surface temperature is approximately $14^{\circ} \mathrm{C}$ ) (IPCC 2007). The speed of warming accelerated as the century progressed. The expected trajectory of warming over the next hundred years is a matter of considerable debate. Existing models predict that global mean surface temperatures will rise by an additional 1 to $5^{\circ} \mathrm{C}$ by the year 2050 .

Global warming is one determinant of precipitation patterns and extreme weather events, such as storms. Higher surface temperatures induce increased evaporation from soils and bodies of water. The resulting elevated concentration of water vapor leads to more precipitation in some places and more droughts in others. Some precipitation that used to fall as snow now falls as rain. In the view of many researchers, extreme weather events are more frequent and more severe as a result of global warming; there are now more extreme warm nights, heat waves, tropical storms, and hurricanes than there were 50 years ago. Figure 1 illustrates a clear upward trend in the number of weather-related natural disasters. The direction of the trend is clear, though the increase may be driven in part by both better reporting practices and increasing human settlement 
in risk areas. In regions such as Latin America and the Caribbean as well as East Asia and the Pacific, the average annual frequency of disasters increased fivefold between the 1970s and the 2000s and increased almost twofold in the most recent two decades (during which changes in measurement techniques were less likely to confound interpretation and inference).

\section{$<<$ Figure 1 about here $>>$}

Agricultural production is often highly sensitive to the weather shocks and shifts associated with climate change. Higher temperatures and changing rainfall patterns may influence crop yields; in recent years, for example, climatic variability related to El Niño Southern Oscillation (ENSO) affected wheat yields in Mexico, cotton and mango growing cycles in Peru, and the incidence of plant diseases in various other parts of Latin America. Cattle and dairy productivity may also suffer: heat waves have been shown to negatively influence milk production in Argentina. Water supply restrictions also reduce productive potential in agriculture. Ocean acidification may damage fish stocks, and sea-level rise may eventually submerge coastal farmlands. Extreme weather events often destroy crops and arable land.

This list is not exhaustive, of course. The point is merely that climate change alters the natural conditions in which agricultural households operate. Although employment in agriculture has fallen over the past half century as developing economies have grown, hundreds of millions of people remain in the sector. For nonagricultural households in rural areas, the environment is sensitive to climate change: roads flood, infrastructure is damaged or destroyed, and diseases flourish or fade.

Perhaps because the term "adaptation” seems relatively straightforward, climate change authorities such as the Intergovernmental Panel on Climate Change and the United Nations Framework Convention on Climate Change Secretariat have not taken it upon themselves to sanction a common definition of the term in the context of climate change (OECD 2006). However, some clarity of definition may be useful for understanding what adaptation means in the context of our discussion. For the purposes of this paper, then, adaptation refers to household-level actions taken (i) in response to observed or expected climate conditions and (ii) with the objective of maintaining or improving household welfare.

Adaptation, in this context, involves a multistage process among household decision makers: first, signal detection, or the identification of a weather or climate event; second, an evaluation of the expected consequences or impacts of that event; third, a response, an observable change in household behavior that stems from the evaluation; finally, feedback, or monitoring the outcomes of the adaptive behavior (Kandlikar and Ribsey 2000). Planting alternative crops in response to changing temperature, moving to a different location to avoid floods or droughts, and insuring against weather-related asset losses could all be considered adaptive actions within this process. Accordingly, we use the term adaptive capacity to denote the extent to which households are able to undertake the processes and actions required to maintain or improve welfare in the face of negative shocks and shifts associated with climate change.

Like the manifestations of climate change, the determinants of adaptive capacity among rural households are numerous. For the purposes of this article, these determinants can be thought to 
fall into two broad categories: (i) economic and physical factors and (ii) behavioral or psychological factors. The former category includes factors traditionally discussed in development literature, such as people's levels of human capital, their access to credit, ownership and control of assets (e.g., land, livestock), and physical mobility. The latter category involves individuals' perceptions of risk and of their own adaptive capacity, which have been the focus of more recent work (e.g., Bryan, Chowdhury, and Mobarak 2011). One view of adaptation to climate change holds that these perceptions are just as important-perhaps more importantthan physical and economic factors in determining adaptive capacity (Grothmann and Patt 2005). ${ }^{3}$

\section{Household Responses to Climate-change Shocks: Protecting Consumption, Income, and Human Capital}

Rural households have been exposed to weather shocks for millennia, and scholars have studied households' responses to these shocks for decades. In many ways, household adaptation to weather shocks associated with climate change is likely to mirror past adaptation to storms, floods, and droughts. In this sense, the empirical evidence on household responses to past weather shocks is instructive. At the same time, the increasing frequency and severity of weather shocks associated with climate change, if detected and evaluated, may produce qualitative changes in household responses. Understanding these potential differences is key to contextualizing existing evidence.

First, the increasing frequency and severity of weather shocks will almost certainly alter the economic and physical factors that determine households' adaptive capacity. Beyond direct damage to physical capital, more frequent and extreme weather events may induce higher levels of precautionary savings, which, in turn, may result in lower investment and a reduction in the long-term income stream. Similarly, farmers may reduce overall productivity in an attempt to mitigate risk by diversifying agricultural production portfolios in a suboptimal manner. To our knowledge, there is little empirical evidence on the cumulative effects of repeated weather shocks.

We might consider the damage to physical assets and the necessity of additional saving or riskmanagement activities to be quantitative or magnitude-based changes in adaptive capacity. The key concept is that climate change will simply scale up the adverse effects of weather shocks as we currently observe them.

Perhaps more significant than these changes in scale, however, are the ways in which increasing frequency and severity of weather shocks may imply qualitative changes in the way that households respond to climate, principally by affecting the behavioral and psychological determinants of adaptive capacity. In particular, trends in climate shocks may reduce households' ability to detect and appropriately evaluate weather-related risk ex ante, thereby widening the gap between optimal and actual adaptive behaviors. Recent theoretical and empirical work suggests that ambiguity aversion may negatively affect investments in insurance, for example (Bryan 2010). In Zimbabwe, farmers have been found to systematically underestimate the risk of drought and to underestimate their own capacity to adapt to it (Patt and Gwata 2002). This 
evidence is suggestive, although little is known empirically about the way in which changes in the frequency or severity of climate shocks affect the appropriateness of adaptive responses.

Despite these potential differences between past and future adaptive behavior and capacity, the existing literature on household responses to weather-related shocks can provide valuable insights into future adaptive behaviors. The central message that emerges from previous work is that although households employ a range of measures to manage risk and shocks, the (often informal) adaptation mechanisms that they employ are generally insufficient for maintaining their welfare in the face of weather shocks. Moreover, some coping mechanisms are economically inefficient and may have adverse long-term consequences. As discussed above, we expect that the increasing frequency and severity of climate shocks will only magnify these insufficiencies.

\section{Consumption Smoothing}

Weather shocks (as compared with household-specific shocks such as illness) pose particular challenges for households intent on smoothing consumption. Because they affect whole communities rather than individuals, they complicate local insurance or reciprocal gift-giving efforts, requiring risk pooling or intervention across a broader set of geographic regions.

To what extent will weather shocks associated with climate change reduce consumption among rural households? A large body of evidence indicates that although rural households' efforts to smooth consumption in the face of weather shocks can significantly mitigate negative effects, the success of these efforts varies dramatically across both communities and households. In a survey of papers based on longitudinal data from southern rural India, for example, Morduch (2003) finds that the effect of transfers between households (i.e., gifts given with the expectation of reciprocity, an active consumption-smoothing strategy) ranges from a 40 percent reduction in total income risk to a 90 percent reduction in total income risk.

Similarly, a study on Thailand finds that variation in rainfall patterns pushed rural households to save more in their efforts to smooth consumption (Paxson 1992). However, a recent study of 162 villages in Ethiopia finds that although some households were able to protect consumption by selling livestock or borrowing from friends and relatives, between 25 and 40 percent of respondents “did nothing” in response to droughts, floods, and hailstorms (Deressa, Hassan, and Ringler 2009).

Existing evidence also suggests that increased weather volatility associated with climate change is likely to have the largest effects on the consumption of poor rural households, which have the fewest assets, human resources, and social networks. A study from rural China finds, for example, that a 10 percent decline in income is associated with a 4 percent decline in consumption among poor households but only a 1 percent decline among nonhouseholds (Jalan and Ravallion 1999). Likewise, evidence suggests that households with greater asset holdings and members who are more educated are better able to protect themselves from the impacts of shocks and to recover afterward. In rural Nicaragua and El Salvador, for example, recent studies show that households with higher levels of education and greater asset holdings are both less 
likely to fall into poverty during an aggregate shock and more successful at growing their incomes in the aftermath (Vakis, Kruger, and Mason 2006; Beneke de Sanelíu and Shi 2004).

In sum, available evidence indicates that households' abilities to smooth consumption in the face of weather-related (and other) shocks are "real and significant but not complete" (Murdoch 1995). The increasing weather volatility associated with climate change is likely to further stretch the capacities of rural agricultural households to protect their consumption and increase the risks of their use of inefficient or costly mechanisms to respond to shocks. The evidence also indicates that the increased frequency and severity of weather shocks is likely to have the greatest impact among the poorest rural households.

\section{Income Smoothing}

In light of their inability to fully smooth consumption in the face of income shocks, rural households dealing with decreasingly predictable returns to agriculture may turn to incomesmoothing strategies, such as altering crop portfolios or diversifying sources of household income. In doing so, households often choose to reduce risk even at the cost of significant foregone returns.

One strategy adopted by households in the absence of formal mechanisms for insuring against production risk is to pursue low-risk, low-return agricultural portfolios. In a rural municipality in southern Peru, for example, farmers plant and cultivate many small, geographically dispersed and less profitable plots to reduce aggregate production variance (Goland 1993). Likewise, farmers in southern India whose production is vulnerable to rainfall variability are more likely to plant low-risk, traditional varieties of rice and castor rather than higher-risk, high-yield (more profitable) varieties (Morduch 1990). High levels of weather variability may also discourage farmers from adopting production-enhancing technologies.

There are significant costs associated with such forms of adaptation; conservative factor allocations may reduce profits and, thus, farmer incomes. In the Peruvian municipality described above, the field-scattering strategy was found to reduce farmers' net yields by about 7 percent (Goland 1993). In the case of southern rural India, microsimulation exercises showed that a onestandard deviation reduction in weather risk (rainfall variability) would increase the average profits for farmers at the bottom of the income distribution by nearly 35 percent (Binswanger and Rosenzweig 1993).

Another way that households adapt to increasingly unpredictable agroclimatic conditions is to diversify their sources of income. Indian households that are vulnerable to transitory shocks, including those induced by weather risk, are more likely than similar households to have a member employed in stable, nonagricultural sectors, even when off-farm employment offers lower wages (Rosenzweig and Stark 1989). Studies from Guatemala, Thailand, and China, among other places, describe similar behavior (see, e.g., World Bank 2005a; Townsend 1995; Jalan and Ravallion 1999).

Increasing weather variability and shocks could therefore lead to movements away from agricultural labor markets. Although diversifying out of agriculture is often associated with income growth and poverty reduction (World Bank 2007), moving into nonagricultural 
employment in response to weather-related shocks is not without its risks. A recent study using panel data from Bangladesh analyzes the evolution of wages in the five years following a massive flood in 1998 (Mueller 2010). Although agricultural labor markets there experienced short-term negative consequences due to the flood, nonagricultural labor markets performed worse than agricultural labor markets in the medium term.

\section{Human Capital Accumulation}

Human capital accumulation is also highly susceptible to unfavorable weather events. By reducing investment in education and health and by changing the incidence of certain diseases, weather shocks may jeopardize long-term household welfare, increasing susceptibility to future shocks and increasing the likelihood of the intergenerational transmission of poverty.

Households in rural India, for example, pull their children out of school to cope with various weather-related income shocks (Jacoby and Skoufias 1997). In Nicaragua, Hurricane Mitch negatively affected the progress of students in school (Ureta 2005). There is some evidence that such transitory coping mechanisms may solidify into permanent losses in human capital investment. Evidence from Mexico shows that children who are withdrawn from school during difficult times are one-third less likely to continue their studies than similar children whose schooling is not interrupted (de Janvry, Finan, Sadoulet, and Vakis 2006). This trend is particularly troubling in light of the fact that education — and female education, in particularappears to dramatically increase households' adaptive capacity (see, for example, Blankespoor, Dasgupta, Laplante, and Wheeler 2010).

These weather-related declines in schooling in rural areas are often associated with increases in households' use of child labor. In Tanzania, for example, there is evidence that transitory income shocks created by accidental crop loss increased child labor, more so among poor than nonpoor households (Beegle, Dehejia, and Gatti 2003). In El Salvador, the fraction of children working outside the household following earthquakes in 2001 more than doubled, from 6.5 to 16.5 percent (Santos 2007). Child labor also increased in rural Nicaraguan households affected by the coffee crisis and in rural Nicaraguan households directly in the path of Hurricane Mitch (Vakis, Kruger and Mason 2006; Baez and Santos 2007).

Weather-related shocks can also have a detrimental impact on the nutritional status of poor rural women and children. Evidence from Ethiopia suggests that households do not smooth consumption across individuals within the household; rather, the nutritional status of women "bears the brunt of adverse shocks" (Dercon and Krishnan 2000). Similarly, Baez and Santos (2007) find that Hurricane Mitch increased the likelihood of early infant malnutrition by an alarming factor of four.

As in the case of education, there is evidence that weather-induced shocks to nutrition can have adverse long-term consequences on household welfare. In Zimbabwe, for example, a recent study of young children who became stunted as a result of a drought finds that those affected never fully recovered. Specifically, the study found lasting negative effects not only on affected children's body weights but also on their school attainment and subsequent earnings (Alderman, Hoddinott, and Kinsey 2006). 
Climate change may also affect health more directly by changing the incidence of diseases. Malaria and dengue, for example, which are mosquito-borne diseases, flourish in warm, humid conditions, depending on stagnant water (where mosquitoes breed) and wet air (in which adult mosquitoes can best survive). Cholera and diarrheal diseases are also water-borne. Several studies have shown that the prevalence of these diseases increased in the wake of heavy rainfall caused by El Niño in various years in Ecuador, Bolivia, Peru, Colombia, and Venezuela (Vos, Velasco, and Labastida 1999, WHO 1999, Bouma et al. 1997, Bouma and Dye 1997). Extremes of heat and cold are also linked to higher morbidity and mortality, mostly among the elderly (Rumel et al. 1993, Shumway, Azari, and Pawitan 1988, Bull and Morton 1978).

\section{Household Adaptation to Long-term Shifts in Temperature and Rainfall Patterns}

Thus far, this paper has focused on how - and how well-rural households may be expected to respond to shocks associated with climate change: tropical storms, droughts, floods, and other extreme weather events. We now turn to gradual shifts in temperature and rainfall patterns. Discrete weather-related shocks and gradual shifts in temperature and precipitation levels associated with climate change are, of course, intimately related. The effective distinction that we draw here is that shocks represent deviations from a local mean, whereas shifts represent long-term changes in the mean.

For rural households, these two phenomena require different types of adaptive behaviors. Shocks require efforts to smooth consumption and income, whereas shifts require longer-term —and perhaps permanent - changes in households' methods of income generation. Long-term climate shifts also complicate the task of insuring against weather shocks because traditional insurance mechanisms are designed to address variations in the mean of some variable of interest (e.g., agricultural productivity or income) as opposed to secular changes in the means of those variables over time.

The existing evidence on farmers' perceptions of climate change indicates that farmers often recognize long-term shifts in environmental conditions and that they attempt to respond to these shifts. In a recent survey conducted by IFPRI in Sub-Saharan Africa, more than half of the respondents stated that they perceived long-term increases in temperature and decreases in precipitation (Nhemachena and Hassan 2007). They also indicated that a lack of credit and a lack of information were significant barriers to adaptation.

There are a number of ways in which households might try to adapt to gradual, long-term changes in climactic conditions. Climate shifts may induce households to (i) adapt their use of agricultural inputs and technologies; (ii) diversify their sources of household income, either within agriculture or toward nonagricultural enterprises; or (iii) emigrate from affected regions, all in an attempt to compensate for the adverse effects of climate shifts on agricultural productivity, farm profitability, and household income.

Directly measuring how_and how effectively_households adapt to long-term climate shifts is difficult because doing so requires long panels linking household production behavior, productivity, and income to climate variables, data that largely do not exist at present. Most panel evidence captures household economic mobility and its determinants over relatively short 
periods of time, on the order of five years. ${ }^{4}$ One recent study of a village in the Philippines uses a unique 30-year panel of household data to examine the factors that enable household economic mobility (Fuwa 2007). The study finds that in addition to economic growth (which is found to be an important driver of household economic mobility), education plays a critical role in upward economic mobility. Assets—specifically, land holdings-are found to be important in preventing downward mobility among rural farm households. ${ }^{5}$ The study does not examine the effect of changing climate conditions, however.

Despite the paucity of long-term panel data, a large body of empirical literature on developing countries that examines adaptation to long-term economic changes can inform our consideration of how well rural households — particularly poorer households — will adapt to long-term climate shifts.

\section{Adapting Agricultural Input Use and Adopting New Technologies}

Adopting new technologies is one way in which rural agricultural households can adapt to longterm climate shifts. A substantial body of empirical farm studies, some dating back several decades, examines determinants of farm productivity and profitability in developing countries across Asia, Africa, and Latin America. The evidence indicates that not all households are equally capable of adapting their use of productive inputs or adopting new technologies in the face of changes in the economic environment. Studies consistently demonstrate the importance of farmers' education levels in facilitating higher farm productivity through several channels: (i) direct improvements in worker productivity; (ii) increased ability of workers and enterprise managers to make appropriate decisions about the most efficient mix of inputs and technologies in production; (iii) increased ability of decision makers to adapt to changing technologies, policies, and the external economic environment; and (iv) at sufficiently high levels of education, an ability to generate productivity-enhancing innovations. ${ }^{6}$

\section{Diversifying Household Incomes}

Diversifying household income sources, both within agriculture and toward nonagricultural enterprises, is another form of adaptation that can potentially help households manage longerterm climate shifts. The empirical literature suggests that income diversification strategies are often at the heart of rural households' ability to escape poverty (World Bank 2007). However, as the earlier discussion on income smoothing suggests, not all households are equally capable of diversifying their income sources in an efficient, welfare-enhancing way.

Recent evidence using panel data from Nicaragua shows that family education levels, wealth, control of physical and financial assets (specifically, land and credit), more diversified income portfolios in the initial period, and greater access and proximity to markets (and urban centers of nonagricultural activity) are all positively associated with households' economic mobility, income diversification, and income growth (Vakis, Kruger, and Mason 2006). The findings from Nicaragua are consistent with those from other recent panel studies. In El Salvador, for example, households with higher levels of education, greater asset holdings, and greater proximity to markets experienced faster real consumption growth over the period analyzed (Beneke de Sanelíu and Shi 2004). 
Migration

A third form of adaptation that can potentially help households manage longer-term climate shifts is migration away from affected regions, either to other rural areas or to urban areas. Two studies on Brazil find that weather-related factors currently induce emigration from affected areas (Assuncao and Chein Feres 2008, Mueller and Osgood 2009).

Consistent with the evidence on input use, technology adoption, and income diversification, migration appears to be positively associated with people's education levels and income. In addition, the propensity to migrate appears to be positively associated with initial income levels. A recent study from Bangladesh suggests that the poorest households may be least likely to migrate because returns on migration are uncertain and because, relative to wealthier households, the consequences of a negative outcome are severe. Paying for transport to the city and then failing to obtain a job could mean starvation (Bryan, Chowdhury, and Mobarak 2011).

Similarly, analyses of Brazilian and Mexican census data indicate that illiterate people are least likely to migrate, whereas those with higher education have a higher probability of migrating than do other rural inhabitants (World Bank 2007). Higher schooling levels are also associated with higher probabilities of migration from rural areas in China (Du, Park, and Wang 2005).

\section{Directions for Public Policy}

The fact that some rural households, particularly poorer ones, lack sufficient capacity to adapt to climate change suggests an important role for public policy. To date, climate change studies that focus on household adaptation have tended to take one of two approaches to strengthening household adaptation policies. The first approach, common in agency reports, is to establish a comprehensive agenda for action across sectors, often without attention to prioritization across sectors or activities (see, e.g., IPCC 2007). The second, more recent discussion has focused largely on what has been termed a no-regrets approach to fostering household adaptation (see Heltberg, Siegel, and Jorgensen 2009; de la Torre, Fajnzylber and Nash 2009; and World Bank 2009).

The no-regrets approach emphasizes policies and investments that are part of a sound development and poverty-reduction strategy for developing countries, actions that can generate positive net benefits "under all future scenarios of climate change and impacts" (Heltberg, Siegel, and Jorgensen 2009). Such an approach might include, for example, efforts to increase educational attainment among members of rural households, improving poor households' control of economic assets (such as land and livestock), deepening of rural financial markets, and improving rural households' access to markets through further investments in infrastructure.

The evidence presented here suggests that even in the face of considerable uncertainty regarding climate change - or perhaps precisely because of the uncertainties-there may be occasion for more specific attempts to strengthen rural households' adaptation capacity. We highlight three such areas here: (i) systems of information for adaptation, (ii) climate-adapted risk-management 
instruments (such as indexed production insurance), and (iii) social safety nets that are targetable and scalable on the basis of weather events.

\section{Information for Adaptation}

Because signal detection and the evaluation of the expected consequences are critical to households' ability to respond to climate change, developing systems of information for adaptation will may improve households' ability to adapt to both weather shocks and long-term climate shifts.

Indeed, better information on expected rainfall and seasonal temperatures, coupled with appropriate agricultural extension advice, can help farm households to make more appropriate decisions about crop mix, irrigation, the timing of planting, and other ex ante production options. Since the major ENSO event of 1982/1983, various governments have attempted to affect the behavior of agricultural households by producing and disseminating weather forecast information (Magrin et al. 2007). In the northeastern Brazilian state of Ceará, for example, a government agency engaged poor rural households in the Planting Time Program. Households would receive high-yield seeds in exchange for a portion of their crop; the agency would distribute the seeds at a time deemed most suitable for planting, given seasonal weather forecasts. The agency also encouraged households to plant drought-resistant crops before the low-rainfall season of 1991. Various assessments considered this intervention highly successful (Orlove and Tosteson 1999). Likewise, in Mexico, ENSO forecasts have been used to adjust crop mix (Magrin et al. 2007).

The development of effective information systems for adaptation will face important implementation challenges. As Orlove and Tosteson (1999) note, the institutions that produce climate forecasts do not traditionally interact with the institutional end users of those forecasts (such as food security planning agencies), much less with households or individuals. Establishing relationships between producers and users of climate forecasts can be complex. The Brazilian agency mentioned above, for example, struggled with sharp public criticism after issuing incorrect forecasts in the mid-1990s.

In this context, Patt and Gwata (2002) identify six factors that are considered critical if climate forecasts are to be effective in strengthening rural households' ability to adapt to climate change. To induce the desired effect on farmer behavior, climate information needs to be (1) considered credible, (2) communicated by agents who are considered legitimate (that is, not beholden to special interests), (3) calculated at appropriately detailed (that is, local) scales, (4) expressed in terms that the audience can understand, (5) appropriately timed, and (6) relevant to the decisions that farmers actively make. In this sense, the process of developing effective interventions to strengthen household adaptive capacity requires the active participation of the households themselves (Schröter, Polsky, and Patt 2005).

Although it is difficult to quantify the expected gains associated with developing information systems for adaptation, several studies have attempted to estimate how past information dissemination programs have increased net returns to agricultural production. Estimates range from 5 percent for Argentine soybeans (Magrin and Travasso 2001) to 20 percent for Mexican 
maize (Jones 2001). Attention to effective communication strategies and the effective use of new communications technologies may serve to increase net returns associated with the provision of information for adaptation. Efforts to disseminate weather and other information relevant to production via cell phone text messages, a method that is increasingly viable given the high and rising cell phone penetration rates in poor rural areas, could help to expand outreach in some countries while lowering the costs of disseminating information. Such approaches are already being used to deliver market price information to farmers in developing countries. ${ }^{7}$

\section{Climate-adapted Production Insurance}

As discussed above, changes in average temperature and rainfall patterns over time will require adaptation of the traditional insurance model to address the fact that mean climate (and agronomic) conditions change in a systematic way over time. ${ }^{8}$ More frequent and more intense weather shocks may also warrant a closer link between climate variables and production insurance, perhaps building on a small but a growing body of experience with weather-indexed insurance.

Indeed, weather-indexed insurance may hold some potential for mitigating the negative effects of climate change. In an attempt to address the moral hazard and adverse selection issues that plague traditional crop insurance, some insurers now offer products in which payouts are linked to the occurrence of a weather event, such as low rainfall, which can be observed without a costly loss assessment procedure. Larson, Anderson, and Varangis (2004) provide a useful review of weather-indexed insurance and related risk management tools. One difficulty, they note, is that these products require reliable climate-related information and therefore significant weather station infrastructure. Basis risk (that is, the risk that index-based payouts will correspond only poorly with actual losses) may also constitute a significant barrier to the purchase of index insurance products (e.g., Clarke 2011), although informal risk sharing that protects farmers against individual-level idiosyncratic shocks may mitigate the problem of basis risk (Mobarak and Rosenzweig 2012).

Experience with weather-indexed insurance remains relatively limited, but several recent applications are being monitored with interest to determine whether they may have broader applicability in developing countries. For example, weather indices are currently being used for agricultural insurance in Ontario and Alberta, Canada. In Argentina, in light of the positive correlation between rainfall and milk yields, a rainfall insurance contract is being used by a milkproducing cooperative. In Mexico, the agricultural reinsurance company AGROSEMEX recently used weather derivatives to protect part of its crop reinsurance portfolio exposed to weather risks.

Index insurers cannot begin with a few clients and then expand (as in microfinance). Because of the covariate nature of weather shocks, index insurers must begin their operations with many clients in numerous areas (Morduch 2006). In this context, the potential of weather-index insurance to strengthen adaptive capacity may be constrained by smallholder farmers' demand for such instruments, although recent work from India suggests that the availability of informal insurance may increase the demand for index insurance under certain circumstances (Mobarak and Rosenzweig 2012). Several pilot projects, in which information was provided and 
smallholder farmers' demand for insurance was "aggregated" by local producer organizations and cooperatives, such as those in El Salvador and Nicaragua, may provide lessons on how best to link such risk mechanisms to those who need them (Varangis et al. 2003).

\section{Social Safety Nets}

Safety nets represent another important component of a risk management strategy for climate change and are well suited to fortifying households' ability to adapt to both shocks and shifts. In the face of recent shocks (related both to weather and economic shocks), it has become common to call for flexible safety net programs that can respond to affected households' needs without compromising governments' long-term fiscal positions. Indeed, a number of developing countries around the world have adapted their safety net programs to help poor and crisisaffected households deal with the recent food, fuel, and global financial crises.

One example of successful flexibility along these lines is the Honduras Social Investment Fund (FHIS). Credited with limiting the rise of poverty in the wake of Hurricane Mitch (which killed thousands of Hondurans, left one million homeless and inflicted damage equivalent to two-thirds of GDP), the FHIS was a public program created in 1990 to finance small-scale investments in poor communities. Originally conceived as a way to address the social impacts of structural adjustment policies, the FHIS nimbly transformed into an emergency response program after Mitch devastated the country in 1998. Within 100 days of the hurricane, the program approved $\$ 40$ million for 2,100 community projects; by the end of 1999, the FHIS had financed 3,400 projects, four times the number financed in a comparable prehurricane period (Warren 2003). ${ }^{9}$

There have been more recent experiences with safety net programs helping to protect the poor from shocks, including weather shocks. In 2000, Nicaragua established a conditional cash transfer program called Red de Protección Social (RPS). Although this program was developed to address structural poverty and to foster human capital development among the poor, the RPS was also effective in reducing the vulnerability of poor rural households to income shocks. During a sharp downturn in world coffee prices from 2000 to 2003, consumption among coffeegrowing households that were RPS beneficiaries declined by only 2 percent, whereas consumption among coffee-growing households who were not beneficiaries declined by 30 percent (Vakis, Kruger, and Mason 2006). Building on the success of the RPS, the government of Nicaragua introduced a cash-transfer pilot program in a drought-prone region. After a mudslide in eastern Nicaragua, the program quickly responded by transferring resources to all affected households. ${ }^{10}$ An evaluation of the pilot program found that the income and consumption of beneficiaries was significantly more resilient to droughts, price shocks, and health shocks than that of nonbeneficiary families.

One key feature of the Nicaragua pilot was targeting the program, ex ante, to geographic regions of the country that faced elevated levels of weather-related risk (specifically drought risk, in this case). ${ }^{11}$ Indeed, as with climate-adapted insurance mechanisms, safety net programs designed to protect households from increasingly frequent and severe weather shocks must address the increased information-related challenges associated with targeting on the basis of weather risk. Recent advances in mapping technology, combined with increasingly precise weather-risk forecasts, can help policy makers to address these issues. 


\section{Conclusion}

Under the best of circumstances, agricultural livelihoods are difficult to sustain and improve. Even in the friendliest of agronomic environments, small-scale farming can be incredibly challenging and risky. For those rural households in developing countries that depend on agriculture, climate change adds yet another dimension of difficulty to the problem of maintaining and improving welfare. The same is true, albeit via different mechanisms, for rural households whose income does not come primarily from agricultural activity.

This paper has argued that climate change poses two distinct, if interrelated, sets of challenges for poor rural households: challenges related to the increasing frequency and severity of weather shocks and those related to long-term shifts in temperature, rainfall patterns, water availability, and other environmental factors. Although much is unknown about how poor rural households will adapt to these shocks and shifts, a substantial body of empirical evidence from developing countries provides a reasonably robust sense of the strengths and limitations of available adaptation mechanisms.

An important and encouraging finding from the literature is that rural households-even poor ones - possess a number of strategies for mitigating the effects of shocks associated with climate change. They may attempt to smooth consumption in the face of income shocks (using credit, insurance, savings, and other methods), and they may attempt to smooth income (by adjusting agricultural portfolios or diversifying sources of income, for example). The evidence indicates, however, that households' abilities to smooth consumption and income are less than perfect. Moreover, some strategies, such as employing child labor, come with clear risks.

Longer-term climate shifts create other challenges to rural households' livelihoods and call for other types of adaptation responses. Rural agricultural households confronted with significant environmental and agronomic changes due to climate change will need to adjust their livelihood strategies if they are to maintain or increase their incomes. Adapting to climate shifts may require farming households to adjust their cropping choices and alter their use of productive inputs and technologies. Farmer households may also seek to diversify their income sources or to migrate to areas less affected by long-term changes in temperatures and precipitation.

Understanding the factors that affect rural households' capacity to adapt to shocks and shifts will be important in designing effective interventions to strengthen their adaptation capacity. Here, the evidence provides some consistent messages: policies and programs that help to increase households' human capital and improve their access to physical assets, financial capital, and markets can play important roles in strengthening their capacity to adapt to climate change. In this sense, many interventions that can fortify rural households' adaptive capacity are also part of an effective long-term development and poverty-reduction strategy for developing countries. Hence, there is an appeal to a no-regrets approach that focuses on interventions with positive net benefits regardless of how the shocks and shifts associated with climate change unfold. 
Yet, perhaps precisely because of the inherent uncertainties of climate change, an intense focus on the adaptive capacity of rural households warrants consideration. We have discussed three potential focus areas. In addition, investing in improved household data collection and analysis, including the development of longer-term panels of data that can facilitate direct observation and analysis of households' and policy makers' responses to climate-related shocks and shifts, will ultimately improve our understanding of adaptation to climate change in rural areas. 


\section{References}

Alderman H, J. Hoddinott, and B. Kinsey. 2006. "Long Term Consequences of Early Childhood Malnutrition.” Oxford Economic Papers 58 (3): 450-74.

Assuncao, J., and F. Chein Feres. 2008. "Climate Migration.” Background Paper for World Bank Flagship Report on Climate Change in Latin America, Low Carbon, High Growth: Latin American Responses to Climate Change, World Bank Latin American and Caribbean Studies.

Baez, J. and I. Santos. 2007. "Children's Vulnerability to Weather Shocks: A Natural Disaster as a Natural Experiment.” Doctoral Dissertation, Maxwell School of Public Affairs (Syracuse University) and Kennedy School of Government (Harvard University), Syracuse, NY and Cambridge, MA.

Beegle, K., R. Dehejia, and R. Gatti. 2003. “Child Labor, Crops Shocks and Credit Constraints.” NBER Working Paper 10088, Cambridge, MA.

Beneke de Sanfeliu, M. and M. Shi. 2004. Dinámica Del Ingreso Rural En El Salvador. 1. ed. San Salvador, El Salvador: Fundación Salvadoreña para el Desarrollo Económico y Social, FUSADES, 2004.

Binswanger, H. and M. Rozensweig. 1993. "Wealth, Weather Risk and the Composition and Profitability of Agricultural Investments.” The Economic Journal 103: 56-78.

Blankespoor, B., S. Dasgupta, B. Laplante, and D. Wheeler. 2010. "The Economics of Adaptation to Extreme Weather Events in Developing Countries.” Center for Global Development Working Paper 199, Washington, DC.

Bouma M., G. Poveda, W. Rojas, D. Chavasse, M. Quinones, J. Cox, and J. Patz. 1997. "Predicting HighRisk Years for Malaria in Colombia using Parameters of El Niño Southern Oscillation.” Tropical Medicine and International Health 2: 1122-27.

Bouma, M and C. Dye. 1997. “Cycles of Malaria Associated with El Niño in Venezuela.” Journal of the American Medical Association 278: 1772-74.

Bull, G.M. and J. Morton . 1978. “Environment, Temperature, and Death Rates.” Age and Aging 7 (4): 210-24.

Bryan, Gharad. 2010. “Ambiguity and Insurance.”

http://www.asb.unsw.edu.au/schools/economics/Documents/G.\%20Bryan\%20-

\%20Ambiguity\%20and\%20Insurance.pdf

Bryan, Gharad, Shyamal Chowdhury and A. Mushfiq Mobarak. "Seasonal Migration and Risk Aversion.” http://faculty.som.yale.edu/mushfiqmobarak/migration.pdf

Clarke, Daniel. 2011. “A Theory of Rational Demand for Index Insurance.” Department of Economics Discussion Paper Series, Oxford University, No. 572.

Dercon, S. and P. Krishnan. 2000. "In Sickness and in Health: Risk-Sharing Within Households in Rural Ethiopia.” Journal of Political Economy 108 (41): 688-727.

Dercon, S. and J.S. Shapiro. 2007. "Moving on, Staying Behind, Getting Lost: Lessons on Poverty Mobility from Longitudinal Data.” In Moving Out of Poverty: Cross-Disciplinary Perspectives on Mobility, ed. D. Narayan and P. Petesch pp. 77-126. Washington DC and New York: A co-publication of the World Bank and Palgrave Macmillan. 
De Janvry, A., F. Finan, E. Sadoulet, and R. Vakis. 2006. "Can Conditional Cash Transfers Serve as Safety Nets in Keeping Children at School and from Working when Exposed to Shocks?" Journal of Development Economics 79 (2): 349-73.

De la Torre, A., P. Fajnzylber, and J. Nash. 2009. Low Carbon, High Growth: Latin American Responses to Climate Change. World Bank, Washington DC.

Deressa, T., R. Hassan, and C. Ringler. 2009. "Household Vulnerability to Climate Change: The Case of Farmers in the Nile Basin of Ethiopia.” International Food Policy Research Institute Discussion Paper 00935, Washington, DC.

Du, Y., A. Park, and S. Wang. 2005. "Migration and Rural Poverty in China.” Journal of Comparative Economics 33: 688-709.

Fuwa, N. 2007. "Pathways Out of Rural Poverty: A Case Study in Socio-economic Mobility in the Rural Philippines.” Cambridge Journal of Economics 31: 123-44.

Goland, C. 1993, "Field Scattering as Agricultural Risk Management: A Case Study from Cuyo Cuyo, Department of Puno, Peru” Mountain Research and Development 13(4): 317-38.

Grothmann, T. and A. Patt. 2005. “Adaptive capacity and human cognition: The process of individual adaptation to climate change.” Global Environmental Change 15: 199-213.

Heltberg, R. P. Siegel., and S. Jorgensen. 2009. “Addressing Human Vulnerability to Climate Change: Toward a ‘No Regrets’ Approach.” Global Environmental Change 19: 89-99.

Hussain, S.S. and D. Byerlee. 1995. "Education and Farm Productivity in Post-Green Revolution Asia." In Agricultural Competitiveness, Market Forces, and Policy Choices, ed. G.H. Peters and D. Headley, Proceedings of the $22^{\text {nd }}$ Conference of the International Agricultural Economics Association. Dartmouth Publishers, Aldershot, U.K.

Intergovernmental Panel on Climate Change (IPCC). 2007. Climate Change 2007: Impacts, Adaptation and Vulnerability. Contribution of Working Group II to the Fourth Assessment Report of the Intergovernmental Panel on Climate Change, M.L. Parry, O.F. Canziani, J.P. Palutikof, P.J. van der Linden, and C.E. Hanson Cambridge University Press, Cambridge, UK.

Jacoby, H. and E. Skoufias. 1997. "Risk, Financial Markets, and Human Capital in a Developing Country.” Review of Economic Studies 64 (3): 311-35.

Jalan, J. and M. Ravallion. 1999. “Are the Poor Less Well Insured? Evidence on Vulnerability to Income Risk in Rural China.” Journal of Development Economics 58 (1): 61-81.

Jamison, D. T., and L. Lau. 1982. Farmer Education and Farm Efficiency. Baltimore: Johns Hopkins University Press.

Jones, J. 2001. "Comparative Assessment of Agricultural Uses of ENSO-based Climate Forecasts in Argentina, Costa Rica and Mexico: Project Summary.” IAI Initial Science Program - III Project, University of Florida, Gainsville, FL.

Kandlikar, M. and J. Ribsey. 2000. "Agricultural Impacts of Climate Change: If Adaptation is the Answer, What is the Question?” Climate Change 45: 529-39.

Kochar, A. 1999. "Smoothing Consumption by Smoothing Income: Hours-of-Work Responses to Idiosyncratic Agricultural Shocks in Rural India.” The Review of Economics and Statistics 81 (1): 50-61. 
Larson, D., J. Anderson, and P. Varangis. 2004. "Policies on Managing Risk in Agricultural Markets.” The World Bank Research Observer 19 (2): 199-230.

Lockheed, M.E., T. Jamison and L. J. Lau. 1980. "Farmer Education and Farm Efficiency: A Survey.” Economic Development and Cultural Change 29 (1): 37-76.

Magrin, G., C. Gay Garcia, D, Cruz Choque, J. C. Gimenez, A. R. Moreno, G. J. Nagy, C. Nobre, A. Villamizar. 2007. "Latin America." In Climate Change 2007: Impacts, Adaptation and Vulnerability. Contribution of Working Group II to the Fourth Assessment Report of the Intergovernmental Panel on Climate Change, ed. M.L. Parry, O.F. Canziani, J.P. Palutikof, P.J. van der Linden, and C.E. Hanson: 582-615. Cambridge University Press, Cambridge, UK.

Magrin, G. and M. Travasso. 2001. "Economic Value of ENSO-based Climatic Forecasts in the Agricultural Sector of Argentina.” 2nd International Symposium Modelling Cropping Systems, European Society of Agronomy (ESA), Florence, Italy: 139-40.

Mobarak, A. Mushfiq and Mark Rosenzweig. 2012. "Selling Formal Insurance to the Informally Insured.” http://faculty.som.yale.edu/mushfiqmobarak/insurance.pdf

Moock, P.R., and H. Addou. 1994. “Agricultural Productivity and Education.” In International Encyclopedia of Education (Volume 1), ed. T. Husen and N. Postlethwaite. Oxford: Pergamon Press.

Morduch, J. 1995. "Income Smoothing and Consumption Smoothing.” Journal of Economic Literature 37 (4): 1569-1614.” In Insurance Against Poverty, ed. S. Dercon. Oxford: Oxford University Press.

Morduch, J. 2006. “Micro-insurance: The next revolution?” In Understanding Poverty, ed. A. Banerjeee, R. Bénabou, and D. Mookherjee: 337-356. Oxford: Oxford University Press.

Mobarak and Rosenzweig. 2012. "Selling Formal Insurance to the Informally Insured.”

http://faculty.som.yale.edu/mushfiqmobarak/insurance.pdf

Mueller, V. 2010. "Short- and Long-Term Effects of the 1998 Bangladesh Flood on Rural Wages." IFPRI Discussion Paper 00956, Washington, DC.

Mueller, V. and Osgood D. 2009. "Long-Term Consequences of Short-term Precipitation Shocks: Evidence from Brazilian Migrant Households.” Agricultural Economics 40: 573-586.

National Institute of Environmental Health Sciences. 1999. "Environmental Impacts of Hurricane Mitch.” Environmental Health Perspectives 107 (3): A139-40.

Nhemachena, C., and R. Hassan. 2007. "Micro-Level Analysis of Farmers' Adaptation to Climate Change in Southern Africa.” International Food Policy Research Institute Discussion Paper 00714, Washington, DC.

Orlove B. and J. Tosteson. 1999. “The Application of Seasonal to Interannual Climate Forecasts Based on El Niño-Southern Oscillation (ENSO) Events: Lessons from Australia, Brazil, Ethiopia, Peru, and Zimbabwe.” Berkeley Workshop on Environmental Politics. Berkeley: UC Berkeley Working Paper 99-3.

Organisation for Economic Cooperation and Development (OECD; E. Levina and D. Tirpak). 2006. "Key Adaptation Concepts and Terms.” Draft paper, Agenda Document 1, OECD/IEA Project for the Annex 1 Expert Group on the UNFCCC. 
Patt, A. and C. Gwata. 2002. "Effective seasonal climate forecast applications: Examining constraints for subsistence farmers in Zimbabwe.” Global Environmental Change 12: 185-95.

Paxson, C. 1992. "Using Weather Variability to Estimate the Response of Savings to Transitory Income in Thailand.” American Economic Review 82 (1): 15-34.

Rosenzweig, M. and O. Stark. 1989. “Consumption Smoothing, Migration, and Marriage: Evidence from Rural India, Journal of Political Economy 97 (4): 905-26.

Rumel, D., L. Riedel, M. Latorre, and B. Duncan. 1993. "Infarto do Miocardo e Acidente Vascular Cerebral Associados a Alta Temperatura e Monoxido de Carbono em Area Metropolitana do Sudeste do Brasil.” Revista de Saude Publica 27 (1): 15-22.

Santos, I. 2007. "Risk-Sharing and the Role of Inter-Household Transfers after a Natural Disaster. Evidence from Hurricane Mitch in Nicaragua.” Doctoral Dissertation, Kennedy School of Government, Harvard University, Cambridge, MA.

Schröter, D., C. Polsky, and A. Patt. 2005. “Assessing Vulnerabilities to the Effects of Global Change: An Eight-Step Approach.” Mitigation and Adaptation Strategies for Global Change 10: 573-96.

Shumway, R., A. Azari, Y. Pawitan. 1988. "Modeling Mortality Fluctuations in Los Angeles as Functions of Pollution and Weather Effects.” Environmental Research 45: 224-41.

Timmins, C. 2003. "Health and Climate Change in the Developing World: The Impact of Global Warming on Brazilian Morbidity Patterns.” Working Paper, Duke University, Durham, NC.

Townsend, R. 1994. “Risk and Insurance in Village India.” Econometrica 62 (3): 539-91.

Townsend, R. 1995. "Financial Systems in Northern Thai Villages.” The Quarterly Journal of Economics 110 (4): 1011-46.

Turner, B.L., R.E. Kasperson, P.A. Matson, J.J. McCarthy, R.W. Corell, L. Christensen, N. Eckley, J.X. Kasperson, A. Luers, M.L. Martello, C. Polsky, A. Pulsipher, and A. Schiller. 2003. "A Framework for Vulnerability Analysis in Sustainability Science." Proceedings of the National Academy of Sciences, United States of America 100: 8074-9.

Ureta, M. 2005. "Hurricane Mitch, Family Budgets and Schooling in Nicaragua.” Working Paper, Department of Economics, Texas A\&M University.

Vakis, R., D. Kruger, and A. Mason. 2006. “Shocks and Coffee: Lessons from Nicaragua.” In Income Stabilization in Agriculture: The Role of Public Policies, Proceedings of the $86^{\text {th }}$ EAAE Seminar, Anacapri, Italy.

Varangis, P., P. Siegel, D. Giovannucci, and B. Lewin. 2003. "Dealing with the Coffee Crisis in Central America: Impacts and Strategies.” World Bank Policy Research Working Paper 2993, World Bank, Washington, DC.

Vos, R., M. Velasco and E. Labastida. 1999. "Economic and Social Effects of El Nino in Ecuador, 9971998.” Inter-American Development Bank, Sustainable Development Department, Technical Paper Series, Washington, DC.

Warren, D. 2003. "Coping with a Natural Disaster: Hurricane Mitch and the Honduran Social Investment Fund.” Spectrum Magazine, Fall: 20-21. 
World Bank. 2005a. "Shocks and Social Protection: Lessons from the Central American Coffee Crisis." Central America Department, Latin America and Caribbean Region, Washington, DC.

World Bank. 2005b. “DR-CAFTA: Challenges and Opportunities for Central America.” Central America Department and Office of the Chief Economist, Latin America and Caribbean Region, Washington, DC.

World Bank. 2007. “World Development Report 2008: Agriculture for Development.” World Bank, Washington, DC.

World Bank. 2010. “World Development Report 2010: Development and Climate Change.” World Bank, Washington, DC.

World Health Organization (WHO). 1999. "El Niño and Health - Protection of the Human Environment.” Protection of the Human Environment: Task Force on Climate and Health, WHO/SPE/HE/99.4, Geneva. 


\section{Figure 1: Climate-related Disasters by Region (1970-2009)}

\section{Total Number of Climate-related Disasters}

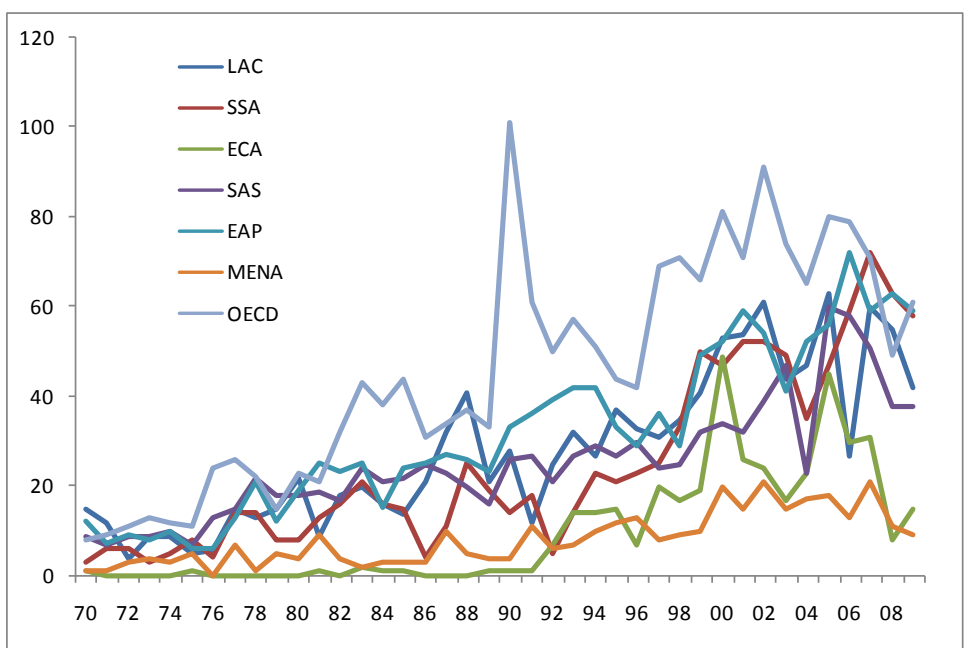

Source: World Bank staff calculations based on EM-DAT: The OFDA/CRED International Disaster Database, Catholic University of Louvain

Note: The count includes events that meet at least one of the following criteria: (1) 10 or more people reported as dead, (2) 100 people reported as affected, (3) a declaration of a state of emergency, or (4) a call for international assistance. LAC (Latin America and the Caribbean), SSA (Sub-Saharan Africa), ECA (East and Central Europe), SAS (South Asia), EAP (East Asia and Pacific), MENA (Middle East and North Africa).

\footnotetext{
${ }^{1}$ Andrew D. Mason is a Lead Poverty Economist with the Poverty Reduction and Economic Management Department, East Asia and Pacific Region, The World Bank, Washington, DC 20433. Email: amason@worldbank.org. Javier Baez is an Economist with the Poverty Reduction and Economic Management Department, Latin America and Caribbean Region, The World Bank, Washington DC 20433. Email: jbaez@worldbank.org. Dorothy Kronick is a doctoral student at Stanford University. Email dkronick@stanford.edu. An earlier version of this article was written as a background paper to the World Bank study for Latin America and the Caribbean, Low Carbon, High Growth: Latin American Responses to Climate Change. The authors gratefully acknowledge support and feedback from Augusto de la Torre, Pablo Fajnzylber, and John Nash, the lead authors of that report, as well as Helena Ribe from the Bank's Human Development Department for Latin America and the Caribbean. We also thank three anonymous referees for their comments. Corresponding author: Andrew D. Mason. The findings, interpretations, and conclusions expressed in this paper are entirely those of the authors. They do not necessarily represent the views of the International Bank for Reconstruction and Development/World Bank and its affiliated organizations, the Executive Directors of the World Bank, or the governments that they represent.

${ }^{2}$ Although climate change creates benefits and opportunities for rural households in regions where expected shifts may actually improve local agronomic conditions, we focus here on household adaptation to expected adverse shocks and shifts.

${ }^{3}$ In the context of climate change, behavioral factors will likely be linked to economic factors through human capital in the sense that people's perceptions of risk and, even, of their own adaptive capacity are a function of their ability to detect and evaluate the actual (or likely) impacts of a weather/climatic event. Although observing and evaluating the impact of shocks may be relatively straightforward, assessing the risks associated with shifts can be much more complex.
} 
${ }^{4}$ Overall, panel studies support the notion that education, assets, access to finance, and access to markets (to different degrees in different places) are important for household income growth and the movement of the poor out of poverty (see Dercon and Shapiro 2007 for a review of evidence). Dercon and Shapiro (2007) also note that risk and shocks serve to inhibit household income growth and mobility. In that sense, households' vulnerability to shocks can affect their ability to adapt to long-term climate shifts.

5 Interestingly, among smallholder farmers, larger landholdings are found to inhibit movement toward nonagricultural employment, perhaps by strengthening these farmers' ties or commitment to farming activities.

${ }^{6}$ Among the studies presenting empirical findings on the relationship between farmer education and agricultural productivity, including the effect of education on input use and technology adoption, see Lockheed et al. 1980; Jamison and Lau 1982; Moock and Addou 1994; Hussain and Byerlee 1995; and World Bank 2007.

${ }^{7}$ For example, seminomadic herders in rural Mongolia can now subscribe to a service through which they can obtain market price data on key commodities in the nearest district towns through their cell phones.

${ }^{8}$ It should be noted that this, by itself, argues for better, more accessible, information on local shifts in temperature and rainfall levels and may generate incentives for the production and dissemination of such information, independent of the perceived demand among rural households.

${ }^{9}$ Projects prioritized clearing debris and repairing or rebuilding water lines, sanitation systems, roads, bridges, health centers, and schools, thus hastening national recovery and generating approximately 100,000 person-months of employment in the three months following the crisis. The decentralized structure and institutional flexibility of the FHIS facilitated its brisk and influential response. Building on strong preexisting partnerships with municipalities and communities, FHIS directors established 11 temporary regional offices and quickly delegated resources and responsibilities. Directors reduced the number of steps in the subproject cycle from 50 to 8, established safeguards to ensure accountability and transparency, and effectively accessed International Development Association financing.

${ }^{10}$ The transfers took place within three months of the event; by the sixth month after the event, RPS had enrolled all affected households as beneficiaries.

${ }^{11}$ Beneficiaries were selected from among RPS enrollees using a proxy-means test. 